собой степень того насколько человек отождествляет себя с профессией и того насколько включен в профессиональное сообщество где общение с коллегами дает возможность получить обратную связь, эмоциональную реакцию и почувствовать принадлежность к значимой социальной группе.

Очень важным моментом является наличие пространства, которое будет для начинающего психолога условно «достаточно хорошей матерью» (Винникот), «среднеожидаемым окружением» ( Э.Эриксон) это способствует развитию идентичности ребенка его потребностей, возможностей и во многом схоже с потребностями начинающего психолога в ходе развития его профессиональной идентичности.

То время, которое может потребоваться на обретение профессиональной идентичности очень индивидуально, по некоторым источникам это несколько лет. Скорость, с которой психолог обретает профессионализм и опытность совершенна разная, хотя существую различные периодизации, где описывают временные промежутки и стадии вхождения в профессию. По нашему мнению приобретение профессиональной идентичности во многом является индивидуальным процессом для каждого человека, так как в чем-то есть определенная схожесть с другими, но это облечено в уникальный опыт каждой личности.

\title{
Литература
}

1. Новикова С.С. Формирование профессионального мышления студентов-психологов / Сборник материалов XIII Всероссийской научнопрактической конференции. Под редакцией И.Б. Шуванова, С.В. Воронина, И.Г. Макаревской, Ю.Э. Макаревской, С.Н. Тесля, В.П. Шувановой. 2014 Издательство (Киров)

2. Новикова C.C. The levels of formedness of future of pedagogues/ psychologists' preparedness for professional orientation/ European Journal of Contemporary Education, №2 (8), 2014, стр. 120-127

3. Винникотт. Семья и развитие личности. Мать и дитя. Екатеринбург, 2004. - C. 400

\section{САМООТНОШЕНИЕ ЛИЧНОСТИ КАК ПСИХОЛОГИЧЕСКАЯ ПРОБЛЕМА. ФЕНОМЕНОЛОГИЯ ПРОИСХОЖДЕНИЯ.}

Каминская А. М.

Одним из важнейших проявлений бытия человека является его отношение к самому себе. Проявление человека как социального существа невозможно без включения процесса самоотношения.

Проблема самоотношения личности является актуальной проблемой исследования и не потеряла своей значимости в настоящее время. Самоотношение как категория психического является для психологии объектом исследования на протяжении целого столетия. Тем не менее, остается до конца неизученной проблемой. Накопленный опыт теоретического анализа и эмпирических данных не дает четкого и однозначного ответа, например, места его в системе Я-концепции, самосознания личности и влияния на становление и 
еe развитие, а так же структуры и динамики самоотношения у людей подверженных девиантному и делинквентному поведению. Наблюдаются пробелы в исследовании самоотношения в отраслевых направлениях психологической науки: таких как клиническая и медицинская психология, психологическое консультирование психокоррекция состояний и черт личности и т.д.

Впервые данный термин начал появляться в середине прошлого столетия в западной научной литературе.

В отечественной психологии исследованием феномена отношения к самому себе, самоотношением активно занимались: И.С. Кон, В.С. Мухина, Е.Т. Соколова. В.В. Столин, Л.С.Выгодский, С.Л. Рубинштейн, А.Н.Леонтьев И.И. Чеснокова, Д.Н.Узнадзе. А.Г. Спиркина.

За рубежом проблему самоотношения разрабатывали: Р. Берне, К.Роджерс, А. Маслоу, У. Джеймс, С.Томсон, Т. Кеш. Вместе с тем единого понятийного и категориального аппарата, а так же единого подхода к рассмотрению данной проблемы нет.

В отечественной научной литературе для описания данного феномена используются, зачастую такие синонимичные понятия как глобальная самооценка, самоуважение, самопринятие, эмоционально-ценностное отношение к себе, собственно самоотношение, аутосимпатия, эмоциональный компонент самооценки и т.д. Их содержание раскрывается с помощью таких психологических категорий как «установка» Д.Н.Узнадзе, «личностный смысл» A.Н. Леонтьев, «отношение» В.Н.Мясищев, «аттитюд» M.Rosenberg, R.Wylie, S.Coopersmit, «социальная установка» И.С.Кон, Н.И.Сарджвеладзе, «чувство» С.Л.Рубинштейн. Все это привело к отсутствию четкого определения понятия самоотношения.

В англоязычной литературе используются такие термины как self-regard (самоотношение), self-esteem (самоуважение, обобщенная самооценка), selffeeling (самочувствие), attitude (любовь к себе), self-respect (самоуважение), selfacceptance (самопринятие), self-attitude (самоотношение, установка на себя), self-evaluation (декларируемая, публичная самооценка) и т. п.

Сам термин самоотношение был впервые введен советским ученым представителем школы установки возглавляемой Д.Н. Узнадзе, Н.И. Сарджвеладзе[1]. Самоотношение определялось им как отношение субъекта потребности к ситуации ее удовлетворения, которое направленно на самого себя. Ученый считал, что самоотношение складывается из отношения к себе вместе с социальным статусом и установкой к внешнему миру. Самоотношение с его точки зрения является структурной единицей системы «личности социальный мир».

Глобальная самооценка как термин был введен У. Джеймсом. В отечественной психологии под глобальной самооценкой преимущественно понимается как аффективное интегративное образование личности, совокупность самопознания и эмоционально-ценностного самоотношения, самоуважения [2]. 
Выделяют три подхода в описании механизмов формирования глобальной самооценки как совокупность интеграции частных самооценок:

- глобальная самооценка как конгломерат частных самооценок, которые связаны с различными аспектами Я-концепции;

- как интегральная самооценка частных аспектов, взвешенных по их субъективной значимости;

- как иерархическая структура, включающая частные самооценки, интегрированные по сферам личностных проявлений и в комплексе составляющие обобщенное «Я», которое находится наверху иерархии [3].

Самоотношение как самоуважение, установка или ее эмоциональный компонент представлено в теории диспозиционной регуляции социального поведения В.А. Ядова и теории установки Д.Н. Узнадзе. Наиболее разработанным считается подход автора рассматриваемого нами феномена Н.И. Сарджвеладзе, который понимает самоотношение как отношение субъекта к ситуации удовлетворения некой потребности, направленное на себя. Здесь самоотношение является подклассом социальной установки наряду с социальным статусом и установкой личности к внешнему миру, определяет, в первую очередь, диспозиции личности, предрасположенность к определенному взаимодействию с социумом.

Наиболее полно и серьезно разработана проблема самоотношения в рамках теории отношений. Представители подхода, изучающие самоотношение как устойчивую черту личности, который был реализован в рамках теории отношений А.Ф. Лазурский и В.Н. Мясищев вводят понятие самоотношение как близкое к такому установочному понятию как самоуважение. Самоотношение в данной теории рассматривается как единство содержательных и динамических компонентов личности и качество эмоционально-ценностного принятия себя и посыл к целенаправленной социальной активности. В данном случае самоотношение понимается как обобщенное одномерное образование, отражающее более-менее устойчивую степень положительности или отрицательности отношения индивида к самому себе [4].

Самоотношение как эмоционально-ценностное отношение к самому себе, то есть как компонент самосознания впервые введенное И.И. Чесноковой и определялось как вид эмоциональных переживаний, в которых отражается собственное отношение личности к тому, что она узнает, понимает, «открывает» относительно самой себя. Представленное как эмоциональная реакция и оценочное суждение о самом себе.

Самоотношение как личностный смысл рассматривали В.В. Столин и С.Р. Пантилеев. Согласно их теории самоотношение следует понимать как непосредственную представленность в сознании личностного смысла «Я», то есть оценку личностью собственных черт по отношению к мотивам, выражающим потребность в самореализации» [5].

Проведенный нами начальный теоретический анализ, в рамках научной статьи, показал сложность, объемность, многомерность и системность феномена, что наталкивает на мысль о дальнейшем исследовании осмыслении 
и оценках, а так же сужении, спецификации области научных исследований. Так же он позволяет выделить существование трех различных подходов в рассмотрении проблемы самоотношения:

- самоотношения как аффективного компонента в концепте самосознания, то есть как единице самосознания;

- устойчивой черты личности ее месте и роли в структуре личности;

- компонента саморегуляции личности.

\section{Литература}

1.Емельянов Ю.Н. Стремление к самотождественности как социальная потребность индивида // Проблемы формирования социогенных потребностей. - Тбилиси: Мицниереба, 1981. - С. 97-100.

2.Столин В.В. Самосознание личности / В.В. Столин. - М.: Издательство московского университета, 1983. - 288 с.

3.Пантилеев С.Р. Самоотношение как эмоционально-оценочная система. М.: МГУ, 1991. $-110 \mathrm{c}$.

4. Гавриленко А.А. Образ физического Я как структурная составляющая Яконцепции: автореф. дис. ... канд. псих. наук / А.А. Гавриленко; ИСУП Государственного университета управления. - М., 2009. - 18 с.

5. Кисляковская В.В., Клецкова И.М. Методологическое обоснование культурно-исторического подхода к пониманию телесности [Электронный ресурс] / В.В. Кисляковская, И.М. Клецкова // СибАк, 2009. - Режим доступа: http://sibac.info/index.php. - 10.03.2014.

6.Столин В.В., Пантилеев С.Р. Опросник самоотношения / В.В. Столин, С.P. Пантилеев // Практикум по психодиагностике: Психодиагностические материалы. - М., 1988. - 123-130 с.

\section{ФОРМЫ ПРОЯВЛЕНИЯ СТРАХА СМЕРТИ}

Кравченко Л.В.

В современном мире, учитывая ритм жизни, человек постоянно сталкивается со сложными, стрессовыми ситуациями, испытывая при этом тревогу. Первоисточником тревожного состояния, по мнению многих исследователей, является страх смерти. Тема смерти и вызывающих ее осознание эмоций была и остается актуальной во все времена истории человечества. Интерес к этой категории возник в умах еще древних философов Сократа, Платона, Эпикура.

Наиболее разработанной, с психологической точки зрения, проблема отношения к смерти предстает в контексте современной теории страха и тревоги. Многие авторы сходятся во мнении, что в основе любого страха лежит страх смерти (физической, психологической, социальной). Различные научные психологические школы (психоанализ, экзистенцианализм, гештальттерапия и другие) занимались этой проблематикой.

Страх смерти дает нам возможность осознания всей ценности нашей жизни, заставляя при этом познать все ее грани, увидеть различные оттенки, 